\title{
An integrated Approach for Corporate Social Responsibility and Corporate Sustainability
}

\author{
Harshakumari Sarvaiya ${ }^{1} \&$ Minyu $\mathrm{Wu}^{2}$ \\ ${ }^{1}$ School of Management, Massey University, Auckland, New Zealand \\ ${ }^{2}$ Division of Business \& Management, BNU-HKBU United International College, Zhuhai, China \\ Correspondence: Minyu Wu, Division of Business \& Management, BNU-HKBU United International College, \\ Zhuhai, 519085, China. Tel: 86-756-362-0181. E-mail: minyuwu@uic.edu.hk
}

Received: April 9, 2013 Accepted: June 3, 2014 Online Published: August 20, 2014

doi:10.5539/ass.v10n17p57

URL: http://dx.doi.org/10.5539/ass.v10n17p57

\begin{abstract}
Balance of power has shifted between the state, society and corporations, which gave birth to the concepts like corporate social responsibility (CSR) and corporate sustainability (CS). Due to the common grounds of CSR and $\mathrm{CS}$, confusion has been created among academics as well as practitioners. This study seeks to identify the relationship between CSR and CS by providing a framework in order to get a better understanding of them. In addition to reviewing the extant literature, we provided empirical support through interviews of CSR or sustainability managers of large New Zealand companies. The key findings of this research revealed that when CSR and CS applications were based on systematic and full fledge focus, there was almost similar kind of initiatives and practices in NZ corporations. To develop an approach to integrating CSR and CS, we support the term, Corporate Sustainability and Responsibility (CS-R). We believe that CS-R help define and clarify the relationship between business and society without denying the great success that CSR has achieved in the academic research, management consulting and media.
\end{abstract}

Keywords: corporate social responsibility, corporate sustainability, sustainable development

\section{Introduction}

For more than half a century, there has been increasing pressure on corporate organisations to balance social and environmental aspects along with economic prosperity. This has led to the evolution of corporate social responsibility (CSR) and other related constructs, such as corporate sustainability (CS), business ethics, corporate citizenship, and stakeholder management. Carroll (1999) prominently noted that "the CSR concept served as the base point, building block, or point-of-departure for other related concepts and themes, many of which embraced CSR-thinking and were quite compatible with it" (p. 288). Although all such constructs shared a common end, there is an increasing difficulty in the understanding of each concept, its implications, and its relation to others (Schwartz \& Carroll, 2008). For example, confusion has arisen among academics and practitioners concerning the notions and application of CSR and CS (Montiel, 2008). A few studies highlighted the theoretical difference between CSR and CS (Schwartz \& Carroll, 2008), while others recommended that they converged gradually (Dewangga, Goldsmith, \& Pegram, 2008). In addition, a few scholars suggested a complex and contradictory relationship between the two (Steurer, Langer, Konrad, \& Martinuzzi, 2005).

As CSR and CS have caught much attention from both academia and industry, it is needed to avoid miscommunication and facilitate the learning and application of these concepts. In our view, to clarify the two concepts will help researchers and managers to prevent misunderstanding in communication and enhance decision making. In addition, although there have been many studies on the concepts of CSR and CS, few empirical research was concerned with this issue. In other words, more empirical studies are still needed in this area. We share a similar view with Lozano (2005) and Wu (2011) that when we refer to CSR and CS, we are constructing two narratives. Both of them are the results of the learning processes, which are constantly evolving and responding to stakeholders' changing wants and needs. This study seeks to identify the relationship between to CSR and CS by providing a framework in order to get a better understanding of both CS and CSR. Apart from reviewing the extant literature, we provide empirical support through interviews of CSR or Sustainability managers of large New Zealand (NZ) companies. The key findings of this research revealed that when CSR and 
CS applications were based on systematic and full fledge focus, there was almost similar kind of initiatives and practices in NZ corporate.

This paper is organized as follows. The first part of paper will present the definitions regarding the key constructs of CSR and CS. Then on the basis of the literature review, the relationship, similarities and differences between CSR and CS will be discussed. Empirical evidence will be examined in the next section which will be followed by the discussion to develop an approach to integrating CSR and CS. The last section provides a conclusion.

\section{Definitions of the Key Constructs - CSR and CS}

Definitions and the concepts of CSR and CS have proliferated during the past decade (Montiel, 2008; van Marrewijk, 2003), and this development has resulted in ambiguity and uncertainty for researchers and practitioners. CSR can be traced back to 60 years ago (Carroll, 1999), with a journey from being a philanthropic approach to a strategic approach to balance economic, social, and environmental dimensions (Branco \& Rodrigues, 2006). On the other hand, CS became popularised in 1980s through a report of the World Commission on Environment and Development (WCED) focusing on ecological sustainability (WCED, 1987). Recently CS has, however, been moulded in broader terms by encompassing three aspects: economic, social, and environmental (Benn \& Dunphy, 2009; Gladwin, Kennelly, \& Krause, 1995; Elkington, 1999). In this section, we discuss the concepts of CSR and CR and how they have expanded from the original narrow notions to a broader strategic approach in terms of tri-dimensional aspects.

\subsection{Corporate Social Responsibility (CSR)}

Dahlsrud (2008) stated that "the definitional confusion surrounding CSR might potentially be a significant problem" (p. 1). A few scholars have attempted to solve this confusion through an analysis of the diverse definitions (e.g., Carroll, 1999; Dahlsrud, 2008). However, there is a lack of any consensus about the concept of CSR thus far. CSR has the oldest history to conceptualise the relationship between business and society (Schwartz \& Carroll, 2008). The concept of social responsibility was first presented by Frank Abrams in a Harvard Business Review article in 1951 (Abrams, 1951). The beginning of the debate on CSR was marked in a landmark study by an American businessman, Howard Bowen, in 1953. He used the term "the social responsibilities of the businessman" and defined CSR as "the obligations of businessmen to pursue those policies, to make those decisions, or to follow those lines of action which are desirable in terms of the objectives and values of our society" (Bowen, 1953, p. 6).

A decade later, several scholars undertook further development of the concept (Davis, 1960; Frederick, 1960; McGuire, 1963). For instance, Davis (1967) extended the definition from "social responsibility of the businessman" to the "social responsibility of businesses", which changed the focus from responsibility of the owners of the enterprise to the whole organisation. In spite of this, the scope of CSR still existed on social welfare and philanthropy. Similarly, social issues were also remained the main agenda of social responsibility during the 1970s. At that time, a widely accepted definition of CSR was developed by the Committee for Economic Development (1971) in publication-Social Responsibilities of Business Corporations; based on a broader view, it suggested that "business functions by public consent and its basic purpose is to serve constructively the needs of society - to the satisfaction of society" (p. 11). Interestingly, Odell (1973) attempted to extend CSR from a stakeholder approach that aims to consider the needs of the society and make positive contributions to all possible interest groups. The most often cited, and the most popular definition, was presented by Carroll (1979), which stated that, "the social responsibility of business encompasses the economic, legal, ethical, and discretionary expectations that society has of organisations at a given point in time" (p. 500).

It was during the late 1970s that academics started to use the term CSR, although it is difficult to pinpoint the exact time when this term came into use. During the 1980s and 1990s, scholars redefined the concept through the course of further research (Carroll, 1999) and CSR was linked with business ethics, corporate social performance, and stakeholder theory, with in-depth studies being carried out in each of these areas (Carroll, 1999; Epstein, 1987; Freeman, 1984; Hopkins, 1998; Tuzzolino \& Armandi, 1981; Wartick \& Chochran, 1985). For example, Jones (1980) recommended to line up social consequences with the business decisions and to consider social cost of these decisions rather than just philanthropy. He also suggested that environmental issue should be merged when implementing CSR. In addition, Tuzzolino and Armandi (1981) argued that CSR must be coupled to the corporate life cycle dynamic. Consequently, CSR was fused with stakeholder theory. To illustrate this, Hopkins (1998) asserted that "CSR is concerned with treating the stakeholders of the firm ethically and in a socially responsible manner. Stakeholders exist both within a firm and outside. Consequently, behaving socially responsibly will increase the human development of stakeholders both within and outside the corporation" (p. 3). 
Recently, CSR evolved as a tri-dimensional concept. Environment was traditionally under-represented as an issue in CSR literature (Dewangga et al., 2008). During the 2000s, however, environmental issues emerged as important part of CSR. In this regard, CSR has been associated with sustainable development and the triple bottom line (profit, people and planet) (Elkington, 1999; Moon, 2007). For instance, the World Business Council for Sustainable Development (WBCSD) (2000) defined CSR, in a more elaborated manner, as being "the commitment of businesses to contribute to sustainable economic development, working with employees, their families, the local community and society at large to improve their quality of life" (p.5). In addition, the Commission of the European Communities (2001) conveyed that CSR is "a concept whereby companies integrate social and environmental concerns in their business operations and in their interactions with their stakeholders on a voluntary basis" (p.6). The current dominant concept of CSR implies that firms voluntarily incorporate social and environmental concerns into their economic operations (Branco \& Rodrigues, 2006). In short, CSR can be defined as the process of integrating economic, social, and environmental issues of corporate firms in order to achieve balanced growth in societies.

\subsection{Corporate Sustainability (CS)}

The concept of CS was derived from the notion of sustainable development (SD) (Schwartz \& Carroll, 2008). The term of SD was first used in the 18th century with reference to the protection of tree populations in forestry and the use of timber in a sustainable way (Ebner \& Baumgartner, 2006). This concept was, however, popularised after a report of the World Commission on Environment and Development (WCED), entitled 'Our Common Future' (better known as Brundtland Report), had been published in 1987 and SD was defined as "development which meets the needs of the present without compromising the ability of future generations to meet their own needs" (WCED, 1987, p. 42). SD originally addressed the implication of ecological- and planetary-wide issues (Moon, 2007). It was perceived to be a societal guiding model. The application of SD at the corporate level is referred to as corporate sustainability (CS) (Dentchev, 2009; Steurer et al., 2005). Although researchers had worked on WCED framework since the late 1980s, sustainability did not gain popularity until 1990s (Montiel, 2008).

According to Schwartz and Carroll (2008), CS was originally considered from the ecological point of view with a limited focus of protecting environment. For example, Hawken (1993) narrated that "sustainability is an economic state, where the demands placed upon the environment by people and commerce can be met without reducing the capacity of the environment to provide for future generations" (p. 139). Shrivastava (1995) also considered sustainability from the environmental viewpoint, suggesting that CS can be achieved through four different mechanisms: total quality environment management; ecological sustainable competitive strategies; technology for nature swaps; and corporate population impact control. In a similar vein, Sharma and Henriques (2005) attempted to map CS from the viewpoint of ecological balancing and evaluated the effect of stakeholders on eco-design, eco-efficiency, and pollution control. Thus, since the early 1990s, studies in the CS field have usually focused on how to protect natural environment while making business decisions and implementing business operations. Similar to CSR, the term of SD was also contested and disputed (Dober, 2009); hence, the notion of CS, which was derived from SD, remain obscure as well.

Social aspects have, however, also been gradually incorporated in the issues of CS. In fact, it is difficult to locate the incident when non-environmental issues became a dimension of CS, but Agenda 21 can be considered to be a milestone indicating this development (Steurer et al., 2005). Although Local Agenda 21 agreements developed at the Rio Conference concentrated both on social and environmental issues, most members initially had a concept that was limited to environmental issues only (Giddings, Hopwood, \& Geoff, 2002). Nevertheless, researchers started to consider social aspects as a part of CS. For instance, based on the first principle of Agenda 21 stating that "human beings are at the centre of concerns for sustainable development", Doyle (1998) argued that social issues should be priority in sustainability thinking. Similarly, the concept of sustainability developed by Gladwin et al. (1995) also focused on social aspects; as they put it, "sustainable development is a process of achieving human development in an inclusive, connected, equitable, prudent, and secure manner" (p. 878).

Social aspect was incorporated into CS along with environmental aspect; however it did not reach a prominent status until the triple bottom line concept of sustainability was introduced by Elkington (1999). According to Elkington, "sustainable development involves the simultaneous pursuit of economic prosperity, environmental quality, and social equity" and organisations in pursuit of CS "need to perform not against a single, financial bottom line but against a triple bottom line" (1999, p. 397). WBCSD (2000) supported this argument, and stated that the integration of social, environmental, and economic considerations is essential to attain SD. Thus, the new 'avatar' of CS is based on three principles: economic integrity, social equity, and environmental integrity (Bansal, 2005). Interestingly, the presence of social consideration in sustainability leads to link CS with CSR. 
For example, Porter (2008) stated that "sustainability refers to actually meeting social and environmental needs in addition to firm profitability, and therefore represents the implementation and outcomes of companies' CSR voluntary intentions" (p. 398). Thus, the construct of CS is not only about managing environmental responsibility, but also about managing social responsibility along with economic prosperity.

\section{A Literature Review on the Relationship between CSR and CS}

The confusing relationship between CSR and CS has increasingly created debate among academics as well as practitioners. For example, Steurer et al. (2005) believed that there was a disorder in the concepts of business and society, namely CSR and CS. According to Wheeler, Colbert and Freeman (2003), the concepts of CSR and CS were inter-woven, which have formed theoretical controversies and conceptual conflict. Furthermore, CSR and CS are vague terms, which are used interchangeably, with both of them being contested concepts (Moon, 2007). There are diverse views among academics on the relationship between CSR and CS.

\subsection{The Relationship between CSR and CS}

A group of scholars believed that CSR is an important contribution to CS and, therefore, they considered CSR as one of the pillar of CS. In their view, CSR could be regarded as the social strand in the tri-dimensional model of CS. For example, Ebner and Baumgartner (2006) reviewed academic articles of eight years in the area of CSR and CS; they recommended that SD is at macro level, while at the micro level, in the organisation, is CS, which encompasses economic, ecological and social pillars, where CSR was modelled as the social pillar of CS. Similar to this thought, Sharma and Rudd (2003) also pointed out that academics studying CS tend to focus on environmental issues, while those studying CSR tend to focus on social and ethical issues. However, they argued that CS is a broad concept and the social aspect is incorporated into CS, meaning that CS encompasses CSR as a social dimension of the sustainability framework.

Another perspective, which considers CS as a broad concept balancing social and environmental aspects, views CSR as a sub-system of CS. For instance, Steurer et al. (2005) studied the complex bond between CS and CSR and stated that "we regard SD, CS and CSR as closely connected, tripartite concepts, yet on different levels of specification with different conceptual nuances" (p. 275). It was concluded that SD is at the normative societal concept which includes CS at corporate level and CSR is a sub-system at management level. In a similar vein, Malovics, Csigene and Kraus (2008) regarded CSR as a means to achieving the objective of CS, by concluding that both external and internal practices of CSR will lead to strong SD. Correspondingly, Wempe and Kaptein (2002) also graphed the relationship between CSR and CS and illustrated CSR as a sub-system of CS to balance profit, people and planet at the organisational level. Some scholars considered CSR as a supplementary stage, or pathway, leading to achievement of CS, as the ultimate goal (Hui, 2008; Moon, 2007; Porter, 2008). In addition, Panapanaan, Linnanen, Karvonen, and Phan (2003) developed a general model of CS and CSR that demonstrated CSR as a sub-system of CS, integrating economic, social and environmental responsibility of the organisation.

On the contrary, quite a few researchers recommended CS as part of CSR. Garriga and Mele (2004) described different theories and approaches used to conceptualise CSR. They considered CS as being a supplementary approach to CSR. Further, Guler and Crowther (2008) also stated that CS is one of the three principles of CSR activity along with accountability and transparency. In a similar tone, Long (2008) argued that CS is an important part of broader CSR programme of corporations, which is responsible for the environment and supply chain practices.

In addition to the above-mentioned relationships between CSR and CS, there are some other arguments proposed by scholars in the literature, which have resulted in confusion to some extent. For example, Gallego (2006) explained that CSR is a tool to measure SD, in terms of economic, social, and environmental aspects, and CS is measured through reporting all of these aspects. On the other hand, Sottorrio and Sanchez (2008) used CS as one of the indicators to measure the CSR performance. Interestingly, Bronn and Vidaver-Cohen (2009) considered sustainability as one of the motives of CSR, whereas Panapanaan et al. (2003) graphed SD as one of the driving factor for CSR. Furthermore, it has been also argued that CSR is one of the factors in the evolution of CS. For instance, Wilson (2003) noted that CSR has contribution towards CS by proving ethical arguments towards sustainability objectives. Zink (2005) pointed out that the European Union's basic message was SD and therefore CSR should be promoted to balance social and environmental concerns, with CSR being a pre-condition to achieving long-term sustainability. Moreover, Dewangga et al. (2008) explored the relation between organisational social responsibility (SR) and SD and recommended that CSR guidelines should be integrated into CS guidelines. As they put it: 
SR should eventually become transformed into full organisational sustainable development planning framework to proactively and effectively assist organisations in moving towards a sustainable society. The majority of both $S R$ and SD experts and academics surveyed, agreed that "Organisational Social Responsibility guidelines such as "CSR guidelines", will eventually become part of overall Organisational Sustainability guidelines ( $p . x$ ).

Schwartz and Carroll (2008) conducted a comparative analysis of five competing concepts, including CSR, business ethics (BE), stakeholder management (SM), sustainability (SD), and corporate citizenship (CC). They argued that there is difficulty in understanding these concepts and relating them to each other. To integrate these five constructs they developed a VBA model (value, balance, and accountability), and proposed that (p.173):

All organisations and individuals operating within a business context have a responsibility (CSR) as good citizens (CC) to (a) contribute to sustainable (SUS) societal value and (b) appropriately balance stakeholder interests(SM), including shareholders or owners and/or moral standards (BE), while (c) demonstrating sufficient accountability.

On the other hand, Panapanaan et al. (2003) commented that "the overlaps of environmental and social issues make it easy for many companies to assume that their sustainable development agenda covers CSR already along with environmental management. However, such assumption is unclear and a grey area for discussion" (p.139). In this regard, there is a lack of consensus to discuss the overlap of the two constructs. Thus, academics have established various relations between CS and CSR, but rather than providing clarity; this has generated a complex web and a vague relationship between the two concepts.

\subsection{Comparison and Contrast of CSR and CS}

\subsubsection{Similarities}

Recently, the term sustainability has been used as a synonym for other concepts such as SD and CSR (Moon, 2007; van Marrewijk, 2003; Wilson, 2003). In addition, CS is considered as a new version of CSR. For example, Faragher (2008) commented that "CSR is old hat - the new buzzword is sustainability" (p.1). Many scholars considered CSR and CS concepts identical in their research work (e.g., Dewangga et al., 2008; Ferns, Emelianova, \& Sethi, 2008; Marsiglia \& Falautano, 2005; Meisinger, 2007; Munoz, Rivera, \& Moneva, 2008; Paul, 2008; Wheeler et al., 2003). According to Guler and Crowther (2008), the recent dialogue on CSR has become the discourse on CS. This was supported by Ebner and Baumgartner (2006) stating that their research sample of previous three years showed a trend to define CSR similarly to CS. Although historically CSR and CS have developed differently, CSR being social issue and CS being environmental issue (Dewangga et al., 2008; Funk, 2003), they are now converging (Kleine \& Hauff, 2009; Montiel, 2008; van Marrewijk, 2003).

In this regard, Montiel (2008) has noted that due to the common end CSR and CS are congregating and conveyed that:

Indeed the conceptualisation of CSR that integrates economic, social and environmental dimensions and the triple bottom line conceptualisation of CS, which comprises economic, social and environmental dimensions, are very similar...thus both CSR and CS aim to balance economic prosperity, social growth and environmental integrity (Montiel, 2008, p. 260).

Recently, both CSR and CS are regarded as voluntary activities, which encompass the environmental and social concerns of the organisation (Lo \& Sheu, 2007; van Marrewijk \& Werre, 2003). Van den Brink and van der Woerd (2004) agreed that confusion exists among companies regarding the implementation of the concepts of CS and CSR. Therefore, they preferred to use the term CS-R, being corporate sustainability and responsibility which is conceptualised by the European Corporate Sustainability Framework (Van Marrewijk \& Hardjono, 2003).

Furthermore, reporting of these social initiatives is identical. Diana (2006) stated that “...the report formerly called the corporate responsibility report, is now called the sustainability report" (p. 46). Even Global Reporting Initiative companies overlap social responsibility reporting with sustainability reporting (Montiel, 2008). Some researchers have used the term CSR-sustainability reporting in their studies, which shows that they do not find CSR and CS reporting different (Ferns et al., 2008; Quaak, Aalbers, \& Goedee, 2007). Paul (2008) studied the websites of the most sustainable Global 100 companies and found that:

Companies use different 12 concepts to report their social performance including sustainability and CSR. More than $50 \%$ companies use CSR word in their web-site reporting, while $29 \%$ companies use sustainability reporting. But due to increasing importance of environmental issues, now companies are moving to use concept of sustainability for their social performance reporting on web sites (Paul, 2008, p. 69). 
According to Montiel (2008), many members belonged to both of the two vibrant groups in the Academy of Management: (1) Social Issues of Management and (2) Organisation and the Natural Environment. In addition, CSR and CS articles were published in both social issues journals and environmental issues journals. Furthermore, a few organisations changed their portfolio from CSR to sustainability. For example, in 1998 the New Zealand Business for Social Responsibility organisation was launched, but in 2002 it merged with the Auckland Environmental Business Network to form the Sustainable Business Network (Roper, 2004). This demonstrated similarities between CSR and CS in terms of objectives and scopes. Hence, there is immense possibility to use these concepts interchangeably.

\subsubsection{Differences}

The literature review reveals that academics have found various differences between CS and CSR. Although theoretically both CSR and CS have the common aspect of balancing economic, social, and environmental issues, CSR is still considered to be a process of managing social issues with stakeholders, while CS is seen as a method for achieving ecological balance (Kleine \& Hauff, 2009).

According to Montiel (2008), CS and CSR are both based on the tri-dimensional base of economic, social, and environmental aspects; however, there are various significant differences. For example, CS researchers considered three aspects as interconnected, while there seems no such link acknowledged by CSR researchers. Another notable difference is that CS tends to be discussed about giving intrinsic value (value of an entity for its own sake independent of its benefit to human kind) while CSR gives 'use value' (benefits for human). Still another issue is that CSR research is always linked with stakeholder theory, while the majority of CS research is associated with the resource-based view and institutional theory (Montiel, 2008).

Similarly, Steurer et al. (2005) also noticed various differences between CS and CSR. Firstly, they argued that CSR is based on expectation of stakeholders, while CS is depends more on a society's interpretation. In addition, they maintained that CSR is a short-term notion that deals with the needs of present stakeholders, while CS is a long-term concept that deals with the needs of future stakeholders. Moreover, they posited that initially, CSR came up from addressing social issues whereas CS focused on environmental issues.

Although van Marrewijk (2003) believed CSR and CS are synonyms, it was argued to draw a thin line between them. The author importantly noted that CSR united people and organisations through transparency, stakeholder dialogue, and sustainability reporting, while CS is the agency principle covering value creation, environmental management, and human capital management.

In fact, CSR is concerned with balancing economic, legal, ethical, and social responsibility, while the CS agenda is ecological dependency and worldwide social impacts (Moon, 2007). Dentchev (2009) compared various related concepts, including CSR and CS, and stated that CSR has its origins in criticism of the neoclassical theory of economics, while CS has its origins in the corporate impacts on society and the environment. It was also stated that CSR is a normative concept, while CS includes a normative, instrumental, and descriptive notions. Thus, the basic differences addressed various issues in the application of CS and CSR.

\section{Research Method}

To examine the current literature and to develop a simplified approach to the concept of CSR and CS, we attempted to investigate views of senior managers of large New Zealand (NZ) corporate. The objective was to examine that which terms are practically used in the organisations, how senior practitioners defined such terms, what are the motives behind these terms and how they implement such practices. The selection of sample companies was based on two criteria: a large New Zealand company (according to revenue) and having a formal CSR practice. First, to select large New Zealand companies according to their revenue, the database of Deloitte New Zealand (2009) was used, which includes a list of the top 200 New Zealand companies and the top 30 banks and financial companies. The top 100 companies and the top 15 banks were considered for further review. It was believed that the companies proactive in CSR would disclose CSR information on their websites (Fenwick \& Bierema, 2008). Therefore, a total of 115 companies' websites were studied to get information about their CSR strategy and initiatives. Following the examination of these websites, 30 companies were found with formal CSR reports, and considerable information about CSR strategy and practice. In the second stage, the CSR managers of these companies were contacted to be involved in this project. Managers from 11 companies accepted the invitation. Semi-structured interviews were conducted during July 2011 to January 2012. The industry grouping of the sampled companies is as follows:

A qualitative data analysis is used for this research, searching for meaning through interpreting the views and behaviours of the participants. Semi-structured interviews were conducted during July 2011 to January 2012. It 
covered the managers mentioned in the above table 1. As shown in the table, out of 11 companies covered in this study, three companies have the position of Sustainability Manager, three companies have CSR or CR Manager, two companies have Corporate Citizenship Manager, one company has Corporate Responsibility and Community Manager, one company has Environment and Health-safety Manager, and one firm has External Affair and Community Investment Manager. However, it was also found that they have similar roles and responsibilities. This is consistent with the report of ACCSR (2007) which found that there are a variety of job titles in the field of CSR with similar job descriptions. A qualitative data analysis is used for this research, searching for meaning through interpreting the views and behaviours of the participants.

Table 1. Profile of organisations sampled in the study

\begin{tabular}{|c|c|c|c|c|}
\hline Company & $\begin{array}{l}\text { Founded } \\
\text { year }\end{array}$ & Industry & $\begin{array}{l}\text { Size of Capital } \\
\text { (NZ\$000) }\end{array}$ & Manager interviewed \\
\hline A & 1908 & Construction & $\$ 5,918,000$ & $\begin{array}{l}\text { Environment and health-safety } \\
\text { manager }\end{array}$ \\
\hline B & 1987 & Telecommunication & $\$ 7,036,000$ & CSR manager \\
\hline $\mathrm{C}$ & 1940 & Airline & $\$ 5,045,000$ & Sustainability Manager \\
\hline $\mathrm{D}$ & 1946 & Petroleum & $\$ 1,177,481$ & $\begin{array}{l}\text { External affair and community } \\
\text { investment manager }\end{array}$ \\
\hline $\mathrm{E}$ & 1999 & Energy & $\$ 7,177,268$ & $\begin{array}{l}\text { Corporate Responsibility } \\
\text { Community manager }\end{array}$ \\
\hline $\mathrm{F}$ & 1933 & Construction & $\$ 1,324,217$ & Corporate Citizenship manager \\
\hline G & 1982 & Retail & $\$ 649,248$ & Sustainability Manager \\
\hline $\mathrm{H}$ & 1830 & Postal services & $\$ 11,303,971$ & CSR Manager \\
\hline I & 1951 & Banking & $\$ 122,915,000$ & Corporate Citizenship manager \\
\hline $\mathrm{J}$ & 1861 & Banking & $\$ 70,772,000$ & Sustainability Manager \\
\hline $\mathrm{K}$ & 1861 & Banking & $\$ 64,557,000$ & CR Manager \\
\hline
\end{tabular}

\section{Voice of Practitioners}

This study found that practitioners usually did not clearly understand CSR and CS. Some managers used these two terms interchangeably, while the others used these terms in narrow and traditional manner. Various researchers supported this argument and noted that even companies are also perplexed in determining their own approaches towards the execution of these concepts (Schwartz \& Carroll, 2008; Lo \& Sheu, 2007; van den Brink $\&$ van der Woerd, 2004).

One of the important findings of this study supports the argument that CS is concerned with ecological or environmental issues only (Hawken, 1993; Sharma \& Henriques, 2005; Shrivastava, 1995). It was noticed that a group of practitioners still believes that sustainable practice means effective environmental actions which is limited to the issue of reduce, reuse and recycle. For example, the Environmental and Health-safety manager of company E defined sustainability as "the way we do in our business does not compromise options for future generation and possibly we enhance the environment for future generation. That is very broad terms and we do that in terms of environmental compliances." Furthermore, a few companies have limited focus for the application of sustainable principles. The sustainability manager of company F pointed out that: "One of the commitments of the company is towards sustainability. And I guess broadly the way our policy works at the moment is around four principles of sustainability; waste minimisation, pollution prevention, sustainable energy use and environmental care. And I guess environmental care is more important about proactive environmental performance." And interestingly, when the manager was asked if they have any social or community practice and he replied that "I think we are doing more about sustainability side!" In other words, it is believed that sustainability and environmental issues are synonyms. Similarly, when manager of company A was asked to define sustainability in his own words, he replied that "Even people who are experts and PhDs in sustainability failed to define it. But according to me, it is about integrating people, profit and planet. However, we mainly focus on environmental material issues only". Moreover, it was also noticed that these firms execute 
sustainability mainly in the areas of environmental compliance, energy efficiency, carbon zero, pollution control, supply chain, monitoring and auditing risk associated with environmental issues, product attributes and climate change, and staff education about environmental issues. Hence, application of sustainability is very limited in these companies.

Due to this limited application of sustainability, sometime practitioners are reluctant to use sustainability term. For instance the citizenship manager of company $\mathbf{J}$ strongly argued that

I am trying extending to more citizenship approach rather than just looking at green sustainability. I totally agree that sustainability term has limited application and that is why we don't even use word sustainability. It is one of the real fade words; it is unfortunate because when you use sustainability in a proper sense it is fantastic. And sustainable business firm should look at across all angels, the same as I look at the citizenship. I think people are connected too much with green party.

In contrast to this, there is also a group of practitioners who accept CSR as community initiative only. For example the corporate responsibility and community manager of Company B defined CSR "as the role of large corporations, and it's responsibilities in the community. Being the largest company, we have got a huge role to play and everything we do affects NZ society. So just acting responsibly is CSR." The corporate citizenship manager of company $\mathrm{G}$ also supported this view by stating that "CSR is about being a good citizen of the country. Business has responsibility towards the community in which they do business. It is about playing an active part in our community through various community projects and managing the relationship with various social and ethical organisations." Adding thoughts in the same vein, the external affairs and community investment manager of company D noted that: "CSR is an important part of doing business. It is about being an important contributor to the community which we operate in and recognising that the community in which we do business are important part of our business and working for community wellbeing. So we have responsibility to the community." It was also found that the scope of CSR is a bit narrow in terms of implementation and the major initiatives are around community projects, volunteering, and relationships with non-profit organisation, community investment, and employee responsibility.

Finally the third stream of practitioners considers CS and CSR as balanced and tri-dimensional approach. This can be illustrated by narration of the sustainability manager of company $\mathrm{K}$ :

Sustainability is thinking about the long term effect of what you are doing today. It's about the well-being of your business, i.e., financially, as well as well-being of your stakeholders. So it's balancing stakeholders' needs and it's also about being a responsible organisation. So it's about the kind of well-being of our society and economy and our planet, our environment. And to me, they all are needed to be linked.

The organisation has very extensive sustainability practice and actively involved in environmental projects, community involvement, sustainable procurement, wellbeing of employees and customers. Similarly the sustainability manager of F Company viewed sustainability as "it is related to doing more with less and doing well by doing good. It is certainly have long term aspiration for the relationship between business and the world and environment and the community." However, when the question comes to implementation, this company mainly focus on environmental aspects while community element was decentralised to business units. Interestingly, the manager argued that "I suspect to see that we will be merging more and more with social-community and wellbeing components of sustainability with our environmental aspects." Hence, the application of sustainability is very broad and multi-dimensional.

In the same direction, many CSR experts also regard CSR as tri-dimensional approach focusing on environment, community and economic issues. The citizenship manager of company J defined CSR as "a responsibility of business that we have towards the environment, towards society, and towards our people and our stakeholders group." Similarly, the CSR manager of company I conveyed:

I think CSR has been born out of people. It is about expressing the role of business and acting responsibly and its responsible action - what it does in relation to stakeholders, its staff, its customers, its impact on the environment and what it does in market place in terms of its product and services.

In a similar vein, the CSR manager of company H noted that: "CSR is about safe guarding the business in terms of our future and it means that business needs to respond not only to the environmental in which it operates but also the communities within which we operate and then to take responsibility for our actions and acknowledge those actions." Moreover, supporting the same philosophy in a novel manner, CSR manager of company C asserted that 
CSR has three parts; in the first instance, it's about being a good business, ensuring fundamental rights and to be fair. So it's about ensuring that as a business, your products and services are ethical and fair, do no harm your customers. In the second instance, it's about being a good employer, ensuring that our people have continuous employment and good work practices and they are able to work in a safe and secure environment. And then in the third instance, it's about understanding what our business responsibility towards broader society is. And for us we use both environment and community in that society because you cannot have one without the other. So you know those three things, being a good business, being a good employer and then understanding responsibility towards society, and in that area both community and environment.

The companies namely J, H, I C, had strategic and integrated CSR practices which focused on environment, market place, workplace, supply chain, and community. They tried to link CSR with almost all operational areas of business. At this point, these practices can be compared with sustainability practices of company K. And there is immense amount of similarity in the application of CSR and CS initiatives and scope of their practices. Hence, it can be summed up that organisations which apply CSR or CS in an appropriate manner, have quite similarity in their execution and scope.

Corporations are often confused on how to relate CSR and CS (Long, 2008). For example, an important point to be noted in this study is that a few companies use CSR and CS terms interchangeably. Company I had a position of CSR manager, and all formal documents of the company acknowledged their initiatives as CSR practice. However, the documents sent to PricewaterhouseCoopers NZ for Sustainable 60 awards recognised the job title of Sustainability manager and their initiatives as Sustainability practice. Furthermore, it was also found that companies attempted to change their positions and focus to variety of related terms. In particular, previously companies put forward the position of CSR Manager, but this position has recently been replaced with that of Sustainability Manager. For instance, we arranged an interview of the CSR manager of company C in November 2010. Surprisingly, when we emailed the manager for confirmation in April 2011, it was known that the manager no more worked with the company and a new person took the new position of SD manager. However, there is no change in the focus and scope of their initiatives. This can also be illustrated by company $\mathrm{J}$ which opted to use term citizenship after a few trail and errors with CSR and CS. The Citizenship manager of the firm J asserted that "Now we are using citizenship term rather than CSR because our stakeholders and employees can better understand what it means to be a good citizen of NZ rather than what is CSR, or other terms". She further added that "social responsibility is something different to all; for some people it is community, for some it is environment and something else across the broad framework. Similarly we tried to used sustainability term but found that its application is limited to just green sustainability." Furthermore, it was also found during the discussion with managers that these terms have similar meaning. For instance, during the discussion with the CSR manager of company $\mathrm{H}$, he pointed out that "There are definite drivers behind the responsible practice of any firm. For us the motivating forces behind our CSR or sustainability or whatever names you call it are..." Hence, based on these participants, it could be argued that practitioners regard these terms as substitutes.

Based on the above findings, it can be concluded that when CSR and CS were implemented with narrow focus, they both were different being CSR as community involvement and CS as environmental issues. However, when CSR and CS applications were based on systematic and full fledge focus, there was almost similar kind of initiatives and practices in NZ corporate. Hence, we suggest that there is a strong opportunity for the perspective of merging both concepts.

\section{Discussion}

The literature review suggests that a diverse and complex relation exists between CSR and CS and so does the empirical evidence. One group of authors considered CSR and CS to be similar concepts. Another group argued that there are basic differences in the two concepts and their applications. The third view came to the conclusion as how CSR and CS relate to each other.

In the first perspective, $\mathrm{CS}$ is considered as a broader concept balancing economic, ecological and social issues and CSR has been viewed as social pillar of this CS model (Ebner \& Baumgartner, 2006; Sharma \& Rudd, 2003). It looks very straight forward; however, it is actually an incomplete recommendation. Although CSR has evolved with social motives, it encompassed environmental and economic issues later on. For example, Carroll (1979) developed a model of social responsibility and mentioned economic responsibility as the foremost social responsibility before ethical, legal or discretionary responsibilities. Furthermore, from more than one decade ago, CSR was conceptually developed and practically implemented as the process of integrating both social and environmental issues (Branco \& Rodrigues, 2006; Commission of the European Communities, 2001; van Marrewijk, 2003) and therefore CSR cannot be considered as the social component of CS only. 
Another alternative provided by the scholars is to consider CSR as a sub-system of CS (Panapanaan et al., 2003; Steurer et al., 2005; Wempe \& Kaptein, 2002). However, as both CSR and CS are the process of balancing economic, social and ecological matters (Lo \& Sheu, 2007; van Marrewijk \& Werre, 2003), there is no logic to consider one approach that overarches the other. For example, van Marrewijk (2003) also argued against this assumption; as he put it, "Although I fully agree with this new domain of CSR and consequently smaller interpretation of the social dimension of the organisation, I doubt if the clock can be reversed" (p.102). Furthermore, none of the research done thus far focused on the practical implication of this relationship and therefore, without empirical evidence, it is not persuasive to put CSR as a sub-system of CS.

A group of authors also indicated that though both CSR and CS have similar agenda, there is a need to define micro differences such as their scope, priorities, motives and implications (Dentchev, 2004; Montiel, 2008; Moon, 2007; Steurer et al., 2005; van Marrewijk, 2003). However, these studies were based on literature review and no empirical ground was provided. Conversely, a group of academics also suggested merging the two concepts for future development and effective implementation. For example, Dewangga et al. (2008) particularly noted that the two separate concepts have come together with a common goal. Therefore, they strongly recommended the collaboration of the two concepts by aligning SD with CSR guidelines (ISO 26000) in order to achieve a long-term sustainable society. In particular, Montiel (2008) suggested to integrate CSR and CS by stating that:

The conceptualizations and measures of CSR and CS seem to be converging, even though there are points of difference between the two constructs. As a result, we should determine whether we need to more accurately distinguish CSR and CS or, on the contrary, whether we should merge them into one construct that will account for all the social and environmental related issues in the management field... Combining some elements of CSR and CS might create a much better definition for firms that are working towards becoming sustainable and socially responsible. (p.26)

Both the literature review and the empirical findings of this study indicated that there is an increasing need to merge the concepts of CSR and CS. In this regard, we share the view of Lozano (2008) who suggested a framework of three aspects: (1) content, (2) structure and (3) process. As argued by Lozano, this framework is very critical for a better understanding of CSR; we believe that it also applies to CS. As for content, Lozano (2008) pointed out that CSR integrates economic, social and environmental dimensions into corporate strategies and decision making, which is quite compatible with CS. Actually, both CSR and CS are working on the quest of the triple bottom line model that embraces profit, people and planet (Panapanaan et al., 2003; Steurer et al., 2005; van Marrewijk, 2003; Wempe \& Kaptein, 2002). Regarding structure, Lozano (2008) argued that CSR proposes a relational perspective on firm management, which emphasises developing and maintaining the relationships with its multiple stakeholders. Garvare and Johansson (2010) developed a theory which suggests that organisation sustainability implies to manage the stakeholders and it will be achieved if the organisation satisfies or exceeds the demand of its stakeholders. Hence, stakeholder theory is an important and commonly used framework within CSR and CS. For process, Lozano (2008) indicated that CSR is portrayed as an innovative and learning journey, in which innovation and learning are demonstrated in a firm's development and implementation of its goals, objectives, and policies. Similarly, $\mathrm{Wu}$ (2011) also argued that corporate sustainability is a continuously changing notion, which is a result of a learning process responding to continual but changing stakeholder demands. To sum up, the concepts of CSR and CS share the common dimensions of content, structure and process. We agree that "CSR and CS as two sides of a coin" (van Marrewijk, 2003, p. 102).

While merging CSR and CS, there is a need for a common terminology to avoid confusion. We need to consider if the new term conveys its message with sufficient clarity. We support the term, Corporate Sustainability and Responsibility (CS-R), used by the European Corporate Sustainability Framework (van den Brink \& van der Woerd, 2004). A similar term, Corporate Sustainability and Responsibility (CSR 2.0), was also suggested by Visser (2011). We believe that Corporate Sustainability and Responsibility (CS-R) can help define and clarify the relationship between business and society without denying the great success that CSR has achieved in the academic research, management consulting and media.

Corporate - As indicated by Lozano (2008), this clearly emphasises that the corporation itself is the point in question. First of all, it limits the subject to the corporation, not a nonprofit organisation. In this respect, as an economic institution, value creation is the most important task of managers. In other words, economic responsibility is a basic requirement for any business where being profitable is a must. Similar to the old term, CSR, CS-R not only stresses the importance of economic aspect, it also highlights that a corporate should take broader responsibility to its multiple stakeholders, including social and environmental aspects. 
Sustainability - We suggest that using sustainability instead of 'social' is to avoid the confusion on the social aspect. The ' $\mathrm{S}$ ' in CSR is quite confusing. On the one hand, it is a broad term that indicates the relationship in general between the corporation and its multiple stakeholders; on the other hand, it only represents the social dimension of a corporation's responsibility, which differs from its economic and environmental aspects (Lozano, 2008). In addition, as mentioned earlier, sustainability tends to be long-term oriented and addresses intergenerational equity. Sustainability could cover both current and future stakeholders.

Responsibility - Why do we not just use the term CS, for it is able to convey the triple bottom line model and the stakeholder concept? As mentioned earlier, the concept of CS is a kind of narrative. Responsibility represents how a corporation responds to the expectations of its multiple stakeholders. Besides, responsibility should take into account all aspects of a corporation's relationships with its stakeholders (Lozano, 2008). In other words, corporate responsibility has economic, social and environmental aspects that are rooted in such relationships. A sustainable corporation must be responsible for its stakeholders and the society as a whole.

\section{Conclusion}

On the basis of the literature review and empirical evidence, it can be concluded that the relationship between CSR and CS is complicated and confusing. There was a comprehensive discussion among academics on the similarities, differences and other relationships between CSR and CS. Although CSR and CS were based on different philosophies at their early stages, they shared a set of common issues. Both of them covered economic, social, and environmental dimensions. In practice, it was shown that CSR and CS were frequently treated as synonyms as well as complementary by managers in companies. They often didn't differentiate between the two concepts, either in application or for reporting. Therefore, we argue that merging the two concepts by a common term would help clarify their meaning and add value to their application. In particular, we suggest to merge the two constructs by using a term CS-R that is similar to the familiar CSR, but stands for 'Corporate Sustainability and Responsibility' (van den Brink \& van der Woerd, 2004). This term clearly represents that a sustainable corporation undertakes a broad responsibility to its current and future stakeholders and the society as a whole. In our view, CS-R is able to clarify the two concepts and would help researchers and managers to prevent misunderstanding in communication and enhance decision making.

\section{References}

Abrams, F. W. (1951). Management's responsibilities in a complex world. Harvard Business Review, 29(3), 29-34.

ACCSR. (2007). The CSR Manager in Australia. South Yara, Vic., Australian: Australian Centre for Corporate Social Responsibility. Retrieved from http://www.accsr.com.au/pdf/ACCSR_Research_Report_CSR_ Managers.pdf

Bansal, P. (2005). Evolving sustainably: A longitudinal study of corporate sustainable development. Strategic Management Journal, 26, 197-218. http://dx.doi.org/10.1002/smj.441

Benn, S., \& Dunphy, D. (2009). Action research as an approach to integrating sustainability into MBA programmes. Journal of Management Education, 33, 276-295.

Bowen, H. R. (1953). Social responsibilities of the businessman. New York: Harper \& Row.

Branco, M., \& Rodrigues, L. (2006). Corporate social responsibility and resource-based perspectives. Journal of Business Ethics, 69, 111-132. http://dx.doi.org/10.1007/s10551-006-9071-z

Bronn, P. S., \& Vidaver-Cohen, D. (2009). Corporate motives for social initiative: Legitimacy, sustainability, or the bottom line? Journal of Business Ethics, 87, 91-109. http://dx.doi.org/10.1007/s10551-008-9795-z

Carroll, A. B. (1979). A three-dimensional conceptual model of corporate performance. Academy of Management Review, 4, 497-505. http://dx.doi.org/10.2307/257850

Carroll, A. B. (1999). Corporate social responsibility: Evolution of a definitional construct. Business \& Society, 38, 268-295. http://dx.doi.org/10.1177/000765039903800303

Committee for Economic Development. (1971). Social responsibilities of business corporations. New York: Committee for Economic Development.

Commission of the European Communities. (2001). Promoting a European framework for corporate social responsibility. Brussels: Commission of the European Communities.

Dahlsrud, A. (2008). How corporate social responsibility is defined: An analysis of 37 definitions. Corporate Social Responsibility and Environmental Management, 15, 1-13. http://dx.doi.org/10.1002/csr.132 
Davis, K. (1960). Can business afford to ignore social responsibilities? California Management Review, 2(3), 70-76. http://dx.doi.org/10.2307/41166246

Davis, K. (1967). Understanding the social responsibility puzzle: What does the businessman owe to society? Business Horizons, 14(4), 45-50. http://dx.doi.org/10.1016/0007-6813(67)90007-9

Dentchev, N. A. (2004). Corporate social performance as a business strategy. Journal of Business Ethics, 55, 395-410. http://dx.doi.org/10.1007/s10551-004-1348-5

Deloitte New Zealand. (2009). Deloitte/Management magazine top 200 New Zealand companies. Auckland: Deloitte New Zealand.

Dentchev, N. A. (2009). To what extent is business and society literature idealistic? Business \& Society, 48, 10-38. http://dx.doi.org/10.1177/0007650307299222

Dewangga, A., Goldsmith, S., \& Pegram, N. (2008). Social responsibility guidelines \& sustainable development: Integrating a common goal of a sustainable society (Unpublished Masters dissertation). Blekinge Institute of Technology, Karlaskrona, Sweden.

Diana, T. (2006). Doing Business the Socially Responsible Way. Business Credit, 108(6), 45-48. Retrieved from http:/connection.ebscohost.com/c/articles/21081011/doing-business-socially-responsible-way

Dober, P. (2009). Corporate social responsibility: Management and methods. Corporate Social Responsibility and Environmental Management, 16, 185-191. http://dx.doi.org/10.1002/csr.201

Doyle, T. (1998). Sustainable development and Agenda 21: The secular Bible of global free markets and pluralist democracy. Third World Quarterly, 19, 771-786. http://dx.doi.org/10.1080/01436599814235

Ebner, D., \& Baumgartner, R. (2006). The relationship between sustainability development and corporate social responsibility. Paper presented at the Corporate Responsibility Research Conference 2006, 4th-5th September, Dublin. Retrieved from http:// www.crrconference.org/downloads/2006ebnerbaumgartner.pdf

Elkington, J. (1999). Cannibals with Forks. Gabriola Island, BC, Canada: New Society.

Epstein, E. M. (1987). The Corporate social policy process: Beyond business ethics, corporate social responsibility, and corporate social responsiveness. California Management Review, 29(3), 99-114. http://dx.doi.org/10.2307/41165254

Faragher, J. (2008, April 22). Sustain to gain. Personnel Today, 20-22.

Ferns, B., Emelianova, O., \& Sethi, S. P. (2008). In his own words: The effectiveness of CEO as spokesperson on CSR-sustainability issues. Corporate Reputation Review, 11, 116-129. http://dx.doi.org/10.1057/crr. 2008.11

Frederick, W. C. (1960). The growing concern over business responsibility. California Management Review, 2(4), 54-61. http://dx.doi.org/10.2307/41165405

Fenwick, T., \& Bierema, L. (2008). Corporate social responsibility: Issues for human resource development professionals. International Journal of Training and Development, 12, 24-35. http://dx.doi.org/10.1111/ j.1468-2419.2007.00293.x

Freeman, R. E. (1984). Strategic management: A stakeholder approach. Boston, MA: Pitman.

Funk, K. (2003). Sustainability and performance. Sloan Management Review, 44(2), 65-70. Retrieved from http://sloanreview.mit.edu/article/sustainability-and-performance/

Gallego, I. (2006). The use of economic, social and environmental indicators as a measure of sustainable development. Corporate Social Responsibility and Environmental Management, 13, 78-97. http://dx.doi.org/10.1002/csr.94

Garriga, E., \& Mele, D. (2004). Corporate social responsibility theories: Mapping the territory. Journal of Business Ethics, 53, 51-71. http://dx.doi.org/10.1023/B:BUSI.0000039399.90587.34

Garvare, R., \& Johansson, P. (2010). Management for sustainability - A stakeholder theory. Total Quality Management \& Business Excellence, 21, 737-744. http://dx.doi.org/10.1080/14783363.2010.483095

Giddings, B., Hopwood, B., \& Geoff, O. B. (2002). Environment, economy and society: Fitting them together into sustainable development. Sustainable Development, 10, 187-196. http://dx.doi.org/10.1002/sd.199

Gladwin, T. N., Kennelly, J. J., \& Krause, T. -S. (1995). Shifting paradigms for sustainable development: Implication for management theory and research. Academy of Management Review, 20, 874-907. 
http://dx.doi.org/10.2307/258959

Guler, A., \& Crowther, D. (2008). Towards equitable sustainability. Ivey Business Journal, 72(1), 1-7. Retrieved from http://iveybusinessjournal.com/topics/social-responsibility/towards-equitable-sustainability\#.U0TkO6 JNTdE

Hawken, P. (1993). The ecology of commerce: A declaration of sustainability. New York: HarperBusiness.

Hopkins, M. (1998). The planetary bargain: Corporate social responsibility comes of age. London: Macmillan.

Hui, L. T. (2008). Combining faith and CSR: A paradigm of corporate sustainability. International Journal of Social Economics, 35, 449-465. http://dx.doi.org/10.1108/03068290810873429

Jones, T. M. (1980). Corporate social responsibility revisited, redefined. California Management Review, 22(3), 59-67. http://dx.doi.org/10.2307/41164877

Kleine, A., \& Hauff, M. (2009). Sustainability-driven implementation of corporate social responsibility: Application of the integrative sustainability triangle. Journal of Business Ethics, 85, 517-533. http://dx.doi.org/10.1007/s10551-009-0212-z

Lo, S. -F., \& Sheu, H. -J. (2007). Is corporate sustainability a value-increasing strategy for business? Corporate Governance: An International Review, 15, 345-358. http://dx.doi.org/10.1111/j.1467-8683.2007.00565.x

Lozano, J. M. (2005). Towards the relational corporation: From managing stakeholder relationships to building stakeholder relationships (waiting for Copernicus). Corporate Governance, 5(2), 60-77. http://dx.doi.org/10.1108/14720700510562668

Lozano, J. M. (2008). CSR or RSC? (Beyond the humpty dumpty syndrome). Society and Business Review, 3 , 191-206. http://dx.doi.org/10.1108/17465680810907288

Long, J. C. (2008). From Cocoa to CSR: Finding sustainability in a cup of hot chocolate. Thunderbird International Business Review, 50, 315-320. http://dx.doi.org/10.1002/tie.20215

McGuire, J. W. (1963). Business and society. New York: McGraw-Hill.

Malovics, G., Csigene, N., \& Kraus, S. (2008). The role of corporate social responsibility in strong sustainability. Journal of Socio-Economics, 37, 907-918. http://dx.doi.org/10.1016/j.socec.2006.12.061

Marsiglia, E., \& Falautano, I. (2005). Corporate social responsibility and sustainability challenges for a bancassurance company. Geneva Papers on Risk \& Insurance - Issues \& Practice, 30, 485-497. http://dx.doi.org/10.1057/palgrave.gpp.2510040

Meisinger, S. (2007). HR's role in social responsibility and sustainability. HR Magazine, 52(12), 8.

Montiel, I. (2008). Corporate social responsibility and corporate sustainability separate pasts, common futures. Organisation \& Environment, 21, 245-269. http://dx.doi.org/10.1177/1086026608321329

Moon, J. (2007). The contribution of corporate social responsibility to sustainable development. Sustainable Development, 15, 296-306. http://dx.doi.org/10.1002/sd.346

Munoz, M. J., Rivera, J. M., \& Moneva, J. M. (2008). Evaluating sustainability in organisations with a fuzzy logic approach. Industrial Management \& Data Systems, 108, 829-841. http://dx.doi.org/10.1108/02 635570810884030

Odell, H. (1973). What does 'social responsibility' of business mean? Academy of Management Proceedings, 597-601. Retrieved from http://connection.ebscohost.com/c/proceedings/4981726/what-does-socialresponsibility-business-mean

Panapanaan, V. M., Linnanen, L., Karvonen, M. -M., \& Phan, V. T. (2003). Roadmapping corporate social responsibility in Finnish companies. Journal of Business Ethics, 44, 133-148. http://dx.doi.org/10.1023/ A:1023391530903

Paul, K. (2008). Corporate sustainability, citizenship and social responsibility reporting. Journal of Corporate Citizenship, (32), 63-78. http://dx.doi.org/10.9774/GLEAF.4700.2008.wi.00007

Porter, T. (2008). Managerial applications of corporate social responsibility and systems thinking for achieving sustainability outcomes. Systems Research and Behavioural Science, 25, 397-411.

Quaak, L., Aalbers, T., \& Goedee, J. (2007). Transparency of corporate social responsibility in Dutch breweries. Journal of Business Ethics, 76, 293-308. http://dx.doi.org/10.1007/s10551-006-9282-3

Roper, J. (2004). Corporate responsibility in New Zealand. Journal of Corporate Citizenship, (14), 22-25. 
Schwartz, M. S., \& Carroll, A. B. (2008). Integrating and unifying competing and complementary frameworks the search for a common core in the business and society field. Business \& Society, 47, 148-186. http://dx.doi.org/10.1177/0007650306297942

Sharma, S., \& Henriques, I. (2005). Stakeholder influence on sustainability practices in the Canadian forest products industry. Strategic Management Journal, 26, 159-180. http://dx.doi.org/10.1002/smj.439

Sharma, S., \& Rudd, A. (2003). On the path to sustainability: Integrating social dimensions into the research and practice of environmental management. Business Strategy and the Environment, 12, 205-214.

Shrivastava, P. (1995). Environmental technologies and competitive advantage. Strategic Management Journal, 16, 183-200. http://dx.doi.org/10.1002/smj.4250160923

Sottorrio, L. L., \& Sanchez, J. L. F. (2008). Corporate social responsibility of the most highly reputed European and North American firms. Journal of Business Ethics, 82, 379-390.

Steurer, R., Langer, M. E., Konrad, A., \& Martinuzzi, A. (2005). Corporations, stakeholders and sustainable development I: A theoretical exploration of business-society relations. Journal of Business Ethics, 61, 263-281. http://dx.doi.org/10.1007/s10551-005-7054-0

Tuzzolino, F., \& Armandi, B. R. (1981). A need-hierarchy framework for assessing corporate social responsibility. Academy of Management Review, 6, 21-28. http://dx.doi.org/10.2307/257137

van den Brink, T. W. M., \& van der Woerd, F. (2004). Industry specific sustainability benchmarks: An ECSF pilot bridging corporate sustainability with social responsible investments. Journal of Business Ethics, 55, 187-203. http://dx.doi.org/10.1007/s10551-004-1901-2

van Marrewijk, M. (2003). Concepts and definitions of CSR and corporate sustainability: Between agency and communion. Journal of Business Ethics, 44, 95-105. http://dx.doi.org/10.1023/A:1023331212247

van Marrewijk, M., \& Hardjono, T.W. (2003). European corporate sustainability framework for managing complexity and corporate transformation. Journal of Business Ethics, 44, 121-132.

van Marrewijk, M., \& Werre, M. (2003). Multiple levels of corporate sustainability. Journal of Business Ethics, 44, 107-119. http://dx.doi.org/10.1023/A:1023383229086

Wartick, S., \& Chochran, P. (1985). The evolution of the corporate social performance model. Academy of Management Review, 10, 758-769.

WBCSD. (2000). Corporate social responsibility: Making good business sense. Geneva: WBCSD. Retrieved from http://www.wbcsd.org/pages/edocument/edocumentdetails.aspx?id=83\&nosearchcontextkey=true

WCED. (1987). Our common future: Report of the World Commission on Environment and Development. Oxford: Oxford University Press. Retrieved from http://www.un-documents.net/our-common-future.pdf

Wempe, J., \& Kaptein, M. (2002). The balanced company: A theory of corporate integrity. Oxford: Oxford University Press.

Wheeler, D., Colbert, B., \& Freeman, R. E. (2003). Focusing on value: reconciling corporate social responsibility, sustainability and a stakeholder approach in a network world. Journal of General Management, 28(3), 1-28.

Wilson, M. (2003). Corporate sustainability: What is it and where does it come from? Ivey Business Journal, $67(6), 1$.

Visser, W. (2011). The ages and stages of CSR: Towards the future with CSR 2.0. CSR International Paper Series, No. 3. CSR 2.0. Retrieved from http://www.csrinternational.org/about/csr2

Wu, M. (2011). Sustainability as stakeholder management. In G. Eweje. \& M. Perry (Eds.), Business and sustainability: Concepts, strategies and changes. Critical studies on corporate responsibility, governance and sustainability (Vol. 3, pp. 223-241). Bradford, England: Emerald.

Zink, K. J. (2005). Stakeholder orientation and corporate social responsibility as a precondition for sustainability. Total Quality Management \& Business Excellence, 16, 1041-1052.

\section{Copyrights}

Copyright for this article is retained by the author(s), with first publication rights granted to the journal.

This is an open-access article distributed under the terms and conditions of the Creative Commons Attribution license (http://creativecommons.org/licenses/by/3.0/). 